\title{
Kansalais- ja työväenopistojen kokeilutoiminta
}

\section{Johdanto}

Vaikka aikuiskasvatusta on Suomessa harjoitettu 1800-luvun lopulta lähtien, on alan järjestelmällinen kokeilu- ja tutkimustoiminta ollut toiminnan laajuuteen verrattuna vähäistä.

Luonnollisesti useat aikuiskasvattajat suorittavat jatkuvasti eräänlaista kokeilutoimintaa pyrkiessään kehittämään omaa työtään ja työskentelymenetelmiään sekä parantamaan työnsä tuloksia. Tässä ei kuitenkaan tarkoiteta tällaista spontaania kokeilua, vaan virallisemmin organisoitua kokeilua etukäteissuunnitelmineen, rahoitusjärjestelyineen ja raportointeineen.

Vasta 1970-luvulla on ruvettu korostamaan kokeilu- ja tutkimustoiminnan merkitystä aikuiskasvatuksen suunnittelussa ja kehittämisessä. Valtioneuvoston periaatepäätöksessä vuodelta 1978 todetaan: "Aikuiskasvatuksen kehittäminen perustetaan jatkuvalle kokeilu-ja tutkimustoiminnalle"'.

Ennen periaatepäätöksen hyväksymistä tutkimus- ja kokeilutoiminnan tärkeyteen olivat kiinnittäneet huomiota kansalaisopistotoimikunta (Komiteanmietintö 1971:A7) sekä aikuiskoulutuskomitea (Komiteanmietinnöt 1971:A9 ja 1975:28).

Kansalais- ja työväenopistojen valtionavusta annettuun lakiin tehtiin vuonna 1974 muutos, jonka mukaan opistot voivat saada valtionapua suorittamaansa valtakunnallisesti merkittävään kokeiluun. Muiden vapaan sivistystyön opintomuotojen valtionapulainsäädännöstä tällainen säännös on tähän saakka puuttunut. Uuteen kansanopistojen valtionavusta annettuun lakiin, joka tuli voimaan :1.8.1984, sisältyy kuitenkin säännös kokeilutoiminnasta. Ensimmäinen kokeilumääräraha saataneen vuoden 1986 valtion tulo- ja menoarvioon. Opintokeskusten valtionapulainsäädännön uudistaminen on myös suunnitteilla ja siihenkin lienee tarkoitus ottaa määräykset kokeilutoiminnan rahoittamisesta.

\section{Mitä kokeilutoiminta on}

Aikuiskoulutuskomitea määritteli kokeilutoiminnan seuraavasti:

Kokeilutoiminta on tutkimusta, jota harjoitetaan osana käytännön koulutustoimintaa ja johon osallistuvat pääasiallisina toteuttajina koulutustoimintaa suunnittelevat ja organisoivat opetustyöstä vastaavat kouluttajat.

Kokeilutoiminnan avulla pyritään yleensä pragmaattisiin tavoitteisiin: opetuskäytännön tai toiminnan sekä tulosten parantamiseen. Kokeilun avulla voidaan pyrkiä esimerkiksi johonkin seuraavista:

- hankkimaan perustietoja jostakin kysymyksestä,

— täsmentämään ongelmanasettelua,

- testaamaan uusien ideoiden käyttökelpoisuutta,

- kokeilemaan erilaisia käytännön sovellutuksia tai ratkaisuja.

Kokeilun ja tutkimuksen suhde on mielenkiintoinen ja pohtimisen arvoinen asia.

Vaikka kokeilu tapahtuu osana käytännön toimintaa ja sen tavoitteet ovat ensisijaisesti pragmaattiset, sillä on yhtäläisyyksiä ja yhteyksiä tutkimuksen kanssa ainakin seuraavis-. sa suhteissa:

1. Tutkimus voi antaa kokeilulle viitekehyksen, selventää kysymyksenasettelua ja käsitteitä, antaa taustatietoja käsillä olevasta ongelmasta ja siten helpottaa ja suunnata kokeilusuunnitelman laatimista.

2. Koottaessa ja analysoitaessa kokeilusta saatuja kokemuksia voidaan käyttää hyväksi tutkimuksen keinoja tai ainakin soveltaa tutkimuksen tiedonhankintaperiaatteita.

3. Tulosten analysoimisessa ja johtopäätösten teossa on niinikään sovellettava tieteellisen ajattelun periaatteita ja tieteen keinoja luotettavuuden ja yleistettävyyden selvittämiseksi.

Tavallaan siis kokeilu lähenee toimintatutkimusta. 


\section{Kansalaisopistokokeilu}

\subsection{Säännökset}

Kokeilutoimintaa koskeva säännös kansalais- ja työväenopistojen valtionavusta annetun lain $(521 / 62$, muutokset $87 / 74$ ja 1078/75) 2 §:n 3 momentissa kuuluu seuraavasti:

Valtakunnallisesti merkittävää kokeilua kouluhallituksen suostumuksella ja sen ohjaamana suorittavan kansalais- ja työväenopiston ylläpitäjälle voidaan myöntää valtion tulo- ja menoarviossa olevan määrärahan rajoissa erityistä kokeiluvaltionavustusta kouluhallituksen harkinnan mukaan.

Kokeilujärjestelmän kannalta tässä säännöksessä ovat olennaisia seuraavat seikat:

Ensinnäkin kokeilun tulee olla valtakunnallisesti merkittävää. Tämä merkitsee sitä, että kokeilun tuloksia tulee voida soveltaa myös muissa kuin kokeiluopistossa, toisin sanoen tulosten tulee olla yleistettävissä. Yleistettävyys puolestaan sisältää tieteellisyyden vaatimuksen.

Toiseksi, kokeiluvaltionavustusta voidaan myöntää vain kansalais- ja työväenopistolle, ei esimerkiksi korkeakoululle. Siten korkeakoulujen mukanaolo kokeilussa, niin suotavaa kuin se onkin, voi toteutua ainoastaan kokeilevan opiston kautta.

Kolmanneksi, kouluhallituksen tehtävänä on kokeilutoiminnan ohjaus. Tällä ilmeisesti korostetaan kokeilun merkitystä osana opistotoiminnan kehittämistyötä.

Neljänneksi, opistojen kokeilutoimintaa voidaan tukea vain valtion tulo- ja menoarviossa olevan määrärahan rajoissa. Siten viime kädessä eduskunta budjettia hyväksyessään on päättänyt myös kokeilutoiminnan volyymista.

\subsection{Kokeilumäärärahat}

Ensimmäinen kokeilumääräraha - suuruudeltaan 100000 markkaa - oli vuoden 1975 valtion tulo- ja menoarviossa. Määräraha ei sen jälkeen ole kasvanut edes inflaation vauhdissa. Vuoteen 1983 määräraha pysyi 100000 markkana ja nousi 110000 markkaan vuonna 1984. Mitään suurimittaista kokeilutoimintaa ei näin pienillä määrärahoilla ole voitu toteuttaa. Vuosittain kokeiluavustusta on myönnetty 4-9 opistolle. Valtionavustuksen suuruus on kokeilusta riippuen vaihdellut muutamasta tuhannesta muutamaan kymmeneen tuhanteen markkaan.

\subsection{Suoritettujen kokeilujen määrä}

\section{Anotut, hyväksytyt ja toteutetut kokeilut}

Kun ensimmäinen kokeilumääräraha vuonna 1975 oli valtion tulo- ja menoarviossa, oli kiinnostus kokeilujen suorittamiseen opistokentässä suuri. Kokeilusuunnitelmia tuli kouluhallitukselle kaikkiaan 21. Yhtenäkään vuonna tämän jälkeen määrä ei ole ollut läheskään yhtä suuri. Kokeiluhakemuksia hyväksyttiin kuusi eli vain $29 \%$. Korkea hylkäämisprosentti johtui määrärahan niukkuudesta, osittain myös kokeilusuunnitelmien tasosta.

Kaikkiaan kuluneen kymmenen vuoden aikana vuosina 1975-1984 on uusien kokeilujen suunnitelmia lähetetty kouluhallitukselle 78 . Näistä on hyväksytty yhteensä 38 kokeiluhakemusta. Hyväksymisprosentti on keskimäärin 47. Hyväksytyistä kokeiluista kolme on eri syistä peruuntunut, joten kokeiluja on suoritettu kaikkiaan 35. Nämä seikat ilmenevät taulukosta 1. Suoritetuista kokeiluista 32 on toteutettu suomenkielisissä ja kolme ruotsinkielisissä opistoissa.

Taulukko 1. Anotut ja hyväksytyt kansalaisopistokokeilut vuosina 1975-1984

\begin{tabular}{lccc}
\hline Vuosi & $\begin{array}{c}\text { Uusien kokeilujen } \\
\text { hakemuksia }\end{array}$ & \multicolumn{2}{c}{$\begin{array}{c}\text { Hyväksytty uusia } \\
\text { kokeiluja } \\
\text { yhteensä }\end{array}$} \\
& & & $\begin{array}{c}\text { \%-osuus } \\
\text { hakemuksista }\end{array}$ \\
& & 6 & 29 \\
1975 & 21 & 3 & 50 \\
1976 & 6 & 4 & 50 \\
1977 & 8 & 3 & 60 \\
1978 & 5 & 6 & 67 \\
1979 & 9 & 6 & 167 \\
1980 & 9 & 3 & 100 \\
1981 & 3 & 2 & 50 \\
1982 & 4 & - & 0 \\
1983 & 6 & 4 & 57 \\
1984 & 7 & 37 & 47 \\
\hline Yhteensä & 78 & & \\
\hline
\end{tabular}

\section{Kokeilujen kesto}

Kokeilut ovat kestoltaan vaihdelleet yhden työkauden kestävästä kokeilusta kolmen tai jossain tapauksessa neljän vuoden pituisiin kokeiluihin. Noin $2 / 3$ suoritetuista kokeiluista on kestänyt yhden työkauden tai työvuoden ja $1 / 3$ on ollut tätä pidempiä. Alkuvuosina kokeilut olivat yleensä lyhyitä. Viime aikoina kuitenkin useita vuosia kestävät kokeilut ovat yleistyneet. 


\section{Kokeilevien opistojen määrä}

Kaikkiaan 57 opistoa, eli noin viidesosa kaikista, on tehnyt kouluhallitukselle aloitteen kokeilusta. Uusien kokeilujen suunnitelmia on esitetty yhteensä 78 . Siten 17 opistoa on anonut kokeiluvaltionavustusta useammin kuin kerran.

Kokeiluvaltionavustuksen turvin on toteutettu 35 kokeilua. Niiden suorittamisesta on vastannut 30 opistoa. Viisi opistoa on siten vienyt läpi kaksi kokeilua.

\subsection{Kokeilujen aihepiirit}

\section{Painopistealueet}

Kouluhallitus on pyrkinyt ohjaamaan kansalais- ja työväenopistojen kokeilutoimintaa aikuiskasvatuksen ja opistotoiminnan kannalta keskeisille alueille. Vuodesta 1976 lähtien on määritelty painopistealueita, joille kokeilutoiminnan on toivottu suuntautuvan. Tällaisia ovat eri vuosina olleet:

- peruskoulun aikuissovellutukset tai peruskouluaineet yleensä, esimerkiksi ohjaus- ja tukitoimenpiteiden kehittäminen näissä aineissa,

- opetusmenetelmien, -järjestelyjen ja työtapojen kehittäminen eri oppiaineissa, esimerkiksi vieraiden kielten, musiikin, yhteiskunnallisten ja luonnontieteellisten aineiden opetuksessa,

- kansalais- ja työväenopistoissa annettavan opetuksen sekä muiden aikuisopintomuotojen yhdistäminen, eli monimuoto-opetus; esimerkiksi lähi- ja etäopetuksen yhdistäminen, radio- ja televisio-opetuksen käyttömahdollisuudet,

- opetuksen yhteissuunnittelu,

- opintoryhmien heterogeenisyyden ongelmat.

\section{Kokeilujen ryhmittelyperusteet}

Käytännössä opistojen kokeilukiinnostus on suuntautunut varsin monenlaisiin aihepiireihin. Kokeilujen yksiselitteinen ryhmittely jonkin tai joidenkin kriteerien mukaan on vaikeaa, sillä yhdessä kokeilussa voi olla monenlaisia aineksia.

Yksi ryhmittelymahdollisuus olisi tarkastella suoritettujen kokeilujen jakautumista painopistealueiden mukaan, toinen tapa olisi aikuiskoulutuksen tehtäväaluejaon (pohjakoulutuksen täydentäminen, ammatillinen aikuiskoulutus, yhteiskunnallinen aikuiskoulutus ja harrastustavoitteinen aikuiskoulutus) mukainen ryhmittely, kolmas hienojakoisempi oppiaine- ryhmittely, neljäs kokeilun kohteena olevien opiskelija- tai väestöryhmien mukaan ja viides esimerkiksi käytetyn työtavan mukaan. Muitakin tarkastelutapoja varmasti löytyisi. Silti mikään niistä ei antaisi täyttä kuvaa opistokokeilujen moninaisuudesta.

Seuraavassa kokeilut on jaoteltu kahteen pääryhmään, toisaalta rekrytointikokeiluihin, toisaalta didaktisiin kokeiluihin sen mukaan, mikä kokeilussa on ehkä ollut olennaisinta. Kumpikin pääryhmä jakaantuu edelleen alaryhmiin. Rekrytointikokeiluissa pyritään hakevan toiminnan tai opiskelijoihin kohdistettujen erityisjärjestelyjen avulla lisäämään osallistumista opintoihin. Didaktisissa kokeiluissa on pääasiallisena kiinnostuksen aiheena opetuksen sisältöjen, menetelmien, opetusjärjestelyjen ym. kehittäminen eri oppiaineissa.

Taulukko 2. Kansalaisopistokokeilujen aihepiirit

Rekrytointikokeilut tai vastaavat

Kohderyhmä/oppiaine

— vuorotyöntekijät (peruskouluopinnot, opetusjärjestelyt yleensä)

- kansalaiskoulun päättäneet nuoret (peruskouluopinnot)

- lapset, nuoret ja aikuiset (taideaineet)

- vangit (peruskouluopinnot)

_ 'vähiten koulutetut"' (avoin korkeakoulu)

- lähiöasukkaat (yhdyskuntatyö)

_ ',kyläläiset"' (kylätoiminta)

- pohjakoulutustaan parantamaan halukkaat, kuten vaille keskiasteen koulutuspaikkaa jääneet tai työelämään pyrkivät (peruskouluopinnot)

- eläkeläiset (opetusjärjestelyt)

Didaktiset tai opetusjärjestelyjä koskevat kokeilut

Oppi aine/työtapa

- taideaineet (musiikki, kuvataide, kudonta, näyttämötyö, luova toiminta)

- vieraat kielet (pienoiskielistudion käyttö, suggestopedinen opetusmenetelmä, Dodsonin kaksikielinen menetelmä, kirjallinen/suullinen kielitaito)

- yhteiskunnalliset ja kasvatustieteelliset aihepiirit

- monivälineopetus (peruskouluopinnot, avoin korkeakoulu)

- projektiopetus (perhekasvatus ja lähikulttuuriin tutustuminen) 2

- opintojen yhteissuunnittelu 1

- itseopiskelun ohjaus (kielet ja peruskouluaineet)

- avoimen korkeakoulun opetus (psykologia, sosiologia, erityispedagogiikka)

- aikuiskouluttajien täydennyskoulutus 


\section{Suoritettujen kokeilujen aihepiirit}

Edellä esitetyn jaottelun mukaisesti - muistaen kuitenkin varaukset ryhmittelyn vaikeudesta ja kokeilujen moniaineksisuudesta taulukossa 2 on esitetty kokeilujen aihepiirit. Noin kolmasosa kokeiluista on ollut luonteeltaan rekrytointikokeiluja ja kaksi kolmasosaa didaktisia kokeiluja.

1970-luvulla suomalaisessa koulutuspolitiikassa alettiin korostaa koulutuksellista tasaarvoa. Myös aikuiskasvatuksessa huomio kiintyi vähiten koulutusta saaneisiin ja heidän opinnolliseen aktivoimiseensa. Tämä heijastui myös kansalais- ja työväenopistojen kokeilutoiminnassa kiinnostuksena hakevaan toimintaan ja yleensä rekrytointikokeiluihin. Rekrytointikokeilut painottuivatkin erityisesti kokeilutoiminnan alkuvaiheessa, mutta niitä on kyllä tehty myöhemminkin. Rekrytointivaiheen lisäksi kokeiluissa on selvitetty myös opintojen edistymistä, loppuunsuorittamista ja tuloksia.

Rekrytointikokeiluista neljä on kohdistunut vuorotyöntekijöiden opiskelumahdollisuuksien parantamiseen, osallistuuhan tämä väestönosa tutkimusten mukaan keskimääräistä vähemmän kansalaisopisto-opintoihin. Muita kohderyhmiä ovat olleet esimerkiksi kansalaiskoulun päättäneet nuoret, eläkeläiset, lähiöasukkaat sekä vangit.

Didaktisissa kokeiluissa on usein ollut esillä taideaineiden opetuksen (musiikki, kuvataide, näyttämötyö) sekä vieraiden kielten opetuksen kehittäminen. Myös sellaiset työtavat kuin projektiopetus, opetuksen yhteissuunnittelu sekä kesäaikana tapahtuva opiskelijoiden itseopiskelun ohjaaminen ovat olleet kokeilujen kohteena. Monimuoto-opetusta, eli kansalaisopisto-opiskelun ja muiden aikuisopintomuotojen yhdistämistä on selvitetty neljässä eri kokeilussa. Kaikkiaan viidessä eri kokeilussa, joista osa rekrytointikokeiluja, on kiinnostuksen kohteena peruskouluaineiden opiskelu, avoimen korkeakoulun opiskelu puolestaan neljässä kokeilussa. Kolmessa taideaineiden kokeilussa on kohderyhmänä aikuisten ohella ollut myös alle 16-vuotiaat lapset ja nuoret.

\section{Kokeilutoiminnan arviointi ja hyödyntäminen}

Miten korkeatasoista kansalaisopistokokeilu sitten on ollut ja miten se on hyödyttänyt kansalais- ja työväenopistojen toiminnan kehittämistä?

On ilmeistä, että kaikki suoritetut kokeilut eivät ole täyttäneet edellä tieteellisyydelle ase- tettuja vaatimuksia. Toisaalta myöskään aikuiskasvatustutkimus ei - niukoista resursseista johtuen - välttämättä ole kehittynyt niin hyvin, että se aina tarjoaisi vankkaa teoreettista pohjaa kokeilulle. Kokeilusuunnitelmien yleinen taso on kuitenkin alkuaikoihin verrattuna kohonnut. Nykyisin lähes kaikki kokeilut toteutetaan jonkinasteisessa yhteistyössä korkeakoulujen kanssa, virallisessa tai epävirallisessa. Useimmiten yhteistyö on järjestetty siten, että kokeiluun mahdollisesti liittyvän tutkimuksen suorittaja tai kokeiluraportin laatija työskentelee korkeakoulun palveluksessa tai sitten kokeilussa on konsultoivana asiantuntijana tällainen henkilö.

Kokeilun tavoitteena oleva valtakunnallinen merkittävyys tarkoittaa sitä, että kokeilun tuloksia pitää voida käyttää hyväksi ja soveltaa myös muissa kuin kokeilevassa opistossa, kokeilevan opiston toimintaahan kokeilu yleensä suoraan hyödyttääkin.

Kokeilujen tulosten hyväksikäyttäminen ja soveltaminen edellyttää tietoa suoritetuista kokeiluista. Kouluhallituksella on julkaisusarja kansalais- ja työväenopistojen kokeiluraporttien julkaisemista varten. Tarkoituksena on jakaa tietoa kokeiluista popularisoidussa muodossa. Kokeiluraportit lähetetään tiedoksi mm. kaikille kansalais- ja työväenopistoille sekä aikuiskasvatusalan järjestöille ja viranomaisille.

Tähän mennessä on julkaistu kaikkiaan 18 raporttia yhteensä 19 kokeilusta. Raporteista 16 on suomenkielistä ja kaksi ruotsinkielistä.

Kovinkaan paljoa ei ole tietoa siitä, miten kokeilujen tuloksia todella käytetään hyväksi toiminnan tai opetuksen kehittämiseksi opistoissa. Viranomaiset eivät ole kokeilutoiminnan pohjalta antaneet uusia määräyksiä opistoille. Opistoilla puolestaan on melko pitkälle menevä vapaus toimintansa järjestämisessä. Siten kokeilutoiminnan tuloksena syntyneitä opetussuunnitelmia, opetusjärjestelymalleja ym. voidaan käyttää hyväksi, jos halutaan, joko sellaisenaan tai paikallisen sivistystarpeen mukaan muunnettuna. 
1. Heinolan ko

2. Mikkelin ko

3. Lohjan ko

4. Espoon ko

5. Seinäjoen to

6. Harjavallan ko

7. Linnalan ko

8. Paltamon ko

9. Heinolan ko

10. Imatran to

11. Viialan to

12. Valkeakosken to

13. Pirkkalan ko ym.

14. Sonkajärven ko

15. Iisalmen ko

16. Valkeakosken to

17. Virkailijain ko

18. Helsingin kaupungin suom. to

19. Enon ko

20. Tervolan ko

21. Vantaan to

22. Jyvälän ko

23. Outokummun opisto

24. Espoon to

25. Kainulan ko

26. LaitilanPyhärannan ko

27. Joensuun vapaaopisto

28. KauhavanHärmäin ko

29. LaitilanPyhärannan ko

30. Nastolan ko

31. NummiPusulan ko
Peruskouluaineiden opetukseen liittyvä hakeva toiminta (vuorotyöntekijät), syksy 1975

Peruskouluaineiden opetukseen liittyvä hakeva toiminta (kansalaiskoulun päättäneet nuoret), syksy 1975, sekä opiskelun seuranta 1975/76-1978/79

Eläkeläisten opinto- ja harrastustoiminta, syyslukukausi 1975

Pienoiskielistudiolaitteiden soveltuvuus kansalais- ja työväenopistojen kieltenopetukseen, syyslukukausi 1975

Opetuksen yhteissuunnittelu kansalais- ja työväenpistoissa, 1975

Kudonnanopetuskokeilu, 1975/76

Luova toiminta lasten ja eläkeläisten keskuudessa, syyslukukausi 1976

Taideopetuskokeilu 1976/77

Lyhytkurssikokeilu vuorotyöntekijöille, 1977/78

C.J. Dodsonin kaksikielinen metodi vieraassa kielessä sekä ns. motivaatio- ja tietopaketin vaikutukset $1977 / 78-1980$ / 81

Perhekasvatuskokeilu, syyslukukausi 1977

Vuorotyöläisten vapaa-ajan opiskelumahdollisuuksien kehittämiskokeilu, 1977/78

Avoimen korkeakoulun opistokokeilu 1978/79. Vähemmän koulutusta saaneiden henkilöiden hakeutuminen avoimen

korkeakoulun yhteiskunnallisiin aineisiin

Peruskouluaineiden opetus vankilassa, 1978/79

Kunnallispolitiikan monivälineopetuskokeilu, 1979/80

Opiskelijoiden itseopiskelun ohjaamiskokeilu, 1979

Kirjallista/suullista kielitaitoa painottavien työtapojen vaikutus oppimistuloksiin, 1979/80

Suggestopedisen opetuksen kokeilu ranskan kielen opetuksessa 1980/81

Periodiopetuksen soveltuvuus viisivuorotyöntekijöille, syyslukukausi 1980

Tervolan harrastajateatterikokeilu, syyslukukausi 1980

Luottamushenkilöiden hallintokuntakohtainen koulutus se-

kä kasvatusalan ja psykologian kunnallinen aikuiskoulutus, 1980/81-1982/83

Pianonsoiton opetuksen järjestäminen 1980/81-1982/83

Yleissivistävän pohjakoulutuksen täydentäminen 1980/

81-1982/83

Kuvataideaineiden taso-opetuskokeilu 1981-1984

Kansalaisopisto yhdyskuntatyön tukena ja lähiöasukkaiden aktivoijana 1981-83

Yhdistetyn lähi- ja etäopetuksen kokeilu peruskoulun oppimäärän suorittamisessa 1982-1985

Aikuisopettajien täydennyskoulutuskokeilu 1982-1984

Kansalaispiston mahdollisuudet kylätoiminnan organisoimiseen ja kehittämiseen $1984-85$

Televisio-opetuksen käyttö kansalaisopistossa 1984-85

$7-15$-vuotiaiden lasten ja nuorten sekä aikuisten taidekasvatuskokeilu 1984-85

Pianon- ja viulunsoiton sekä musiikin teorian- ja sävel-

tapailun opetuksen didaktinen kehittäminen 1984-86

Kokeiluraportti 1/1976

Kokeiluraportit $1 / 1976$ ja

$2 / 1980$

Kokeiluraportti 1/1977

Kokeiluraportti 2/1977

Kokeiluraportti 3/1977

Harjavallan kaupunki julkaissut raportin

Kokeiluraportti $1 / 1979$

Kokeiluraportti 1/1979

Kokeiluraportti 1/1980

Kokeiluraportti 1/1978

Kokeiluraportti 1/1982

Kokeiluraportti 2/1979

Kokeiluraportti 2/1981

Kokeiluraportti 2/1984

Kokeiluraportti 1/1981

Kokeiluraportti 1/1983

Kokeiluraportti 1/1984

Kokeiluraportti 3/1984

Ko 